\title{
Removal efficiency of anionic surfactants from water during UVC photolysis and advanced oxidation process in $\mathrm{H}_{2} \mathrm{O}_{2} / \mathrm{UVC}$ system
}

\author{
Francisco Ríos ${ }^{1}$, Magdalena Olak-Kucharczyk², Marta Gmurek², Stanisław Ledakowicz²* \\ ${ }^{1}$ Department of Chemical Engineering, Spain \\ University of Granada \\ ${ }^{2}$ Lodz University of Technology, Poland \\ Department of Bioprocess Engineering
}

*Corresponding author's e-mail: stanislaw.ledakowicz@p.lodz.pl

\begin{abstract}
Keywords: advanced oxidation process, anionic surfactants, ether carboxylic derivate, $\mathrm{H}_{2} \mathrm{O}_{2} / \mathrm{UVC}$ system, linear alkyl benzene sulfonate, UVC photolysis.

Abstract: Surfactants after their use are discharged into aquatic ecosystems. These compounds may be harmful to fauna and flora in surface waters or can be toxic for microorganisms of the activated sludge or biofilm in WWTP. In order to determine effectiveness of different advanced oxidation processes on the degradation of surfactants, in this study the degradation of anionic surfactants in aqueous solution using photolysis by $254 \mathrm{~nm}$ irradiation and by advanced oxidation process in a $\mathrm{H}_{2} \mathrm{O}_{2} / \mathrm{UVC}$ system was investigated. Two representatives of anionic surfactants, linear alkyl benzene sulphonate (LAS- $\mathrm{R}_{11-14}$ ) and ether carboxylic derivate $\left(\mathrm{EC}-\mathrm{R}_{12-14} \mathrm{E}_{10}\right)$ were tested. The influence of $\mathrm{pH}$, initial surfactant concentration and dose of hydrogen peroxide on the degradation was also studied. Results show outstanding effectiveness of the $\mathrm{H}_{2} \mathrm{O}_{2} / \mathrm{UVC}$ system in the removal of surfactant from aqueous solutions.
\end{abstract}

\section{Introduction}

Surfactants are a wide group of chemical compounds which have a large number of applications in household cleaning detergents, personal-care products, textiles, paints, polymers, pesticides, pharmaceuticals, mining, oil recovery, and the pulp and paper industries (Fernández-Serrano et al. 2014, Zgola-Grześkowiak et al. 2015, Jurado et al. 2013). Moreover, biosurfactants such as saponin, tannin and rhamnolipids JBR 515 and 425 can be applied for heavy metals removal from immobilized activated sludge (Kuczajowska-Zadrożna et al. 2015). After their use, surfactant residues and their degradation products are discharged into aquatic ecosystems in treated or untreated wastewaters, and enter in various environmental compartments such as surface waters, sediments and biota (Ying 2006). Recent studies have demonstrated the persistence and accumulation of surfactants and their biodegradation products in the environment (Sanz et al. 2013, Cserháti et al. 2002, Petrovic et al. 2002, Robert-Peillard et al. 2015). Several of these compounds may be harmful to fauna and flora in surface waters. For example, surfactants may cause acute and chronic effects on sensitive organisms, such as crustaceans and fish (Roberts and Marshall 1995, Ferrara et al. 2005). Moreover, they affect the growth, motility and photosynthetic ability of algae (Rebello et al. 2014). The presence of high concentrations of surfactants in biologic stations of WWTP inhibits aerobic microorganisms, is toxic to anaerobic microorganisms, and produces foams, which leads to the perturbation of treatment process (Aloui et al. 2009, Bozkurt and Sanin 2014).

According to the European Committee of Organic Surfactants and their Intermediates, the total quantity of surfactants excluding soap produced in Western Europe in 2013 was equal to 2.98 million tons (CESIO 2014). It is predicted that the surfactant market will grow with a compound annual growth rate (CAGR) of 6.19\% until 2017 (Markets 2013). The universality of application of these compounds leads to their presence in water environment. The concentration of LAS-R $\mathrm{R}_{11-14}$ in raw sewage ranged from 1 to $15 \mathrm{mg} \mathrm{dm}^{-3}$ while in surface water LAS-R ${ }_{11-14}$ were detected below $0.05 \mathrm{mg} \mathrm{dm}^{-3}$ (HERA 2013). However, the concentration of this compound in industrial wastewater as well as in laundry sewage was found to be about $200 \mathrm{mg} \mathrm{dm}^{-3}$ (Han 2013) and up to $1024 \mathrm{mg} \mathrm{dm}^{-3}$ (Braga 2011), respectively. Therefore, it is required finding the proper methods of their degradation.

Biodegradation is the cheapest method of the pollutants degradation (Chidambara and Quen 2005), however, in many cases surfactants solutions are toxic for microorganisms of the activated sludge or biofilm (Ledakowicz et al. 2005) causing strong inhibition on dehydrogenase activity of activated sludge biomass (Liwarska-Bizukojc and Bizukojc 2008). Furthermore, some surfactant molecules are not readily biodegradable and relatively high residuals as well partially degraded products are found in the treated effluents and receiving waters (Ying 2006). Therefore, a more efficient option for highly concentrated 
surfactant effluents could be the coupling of advanced oxidation and the biological process that could reduce the final concentration of contaminant in the WWTP outlet (Sanz et al. 2013, Lechuga et al. 2014).

Advanced oxidation processes (AOPs) have been extensively studied for the removal of recalcitrant xenobiotic compounds from water and wastewater (Luo et al. 2014). These processes have several advantages over conventional chemical oxidation using potassium permanganate or chlorine, for example higher oxidation potential and no production of potentially carcinogenic chlorinated by-products. Moreover, the oxidants used in AOPs are in situ generated and not persistent, so they do not affect the biological treatment processes (Ikehata and El-Din 2004). The anionic surfactant LAS- $\mathrm{R}_{11-14}$ is relatively well degraded by some AOPs including ozonation, Fenton, photo-Fenton and $\mathrm{H}_{2} \mathrm{O}_{2} / \mathrm{UV}$ processes (Sanz et al. 2013, Pagano et al. 2008, Lechuga et al. 2014). In recent years, study on effective removal of LAS-R ${ }_{11-14}$ and other important non-ionic surfactants is becoming more and more active topic. Some studies, such as this published by Sanz et al. (2013), demonstrated the influence of reaction temperature on the degradation of LAS using a $\mathrm{H}_{2} \mathrm{O}_{2} / \mathrm{UV}$ system. Pagano et al. (2008) studied the oxidation of alcohol ethoxylates and alkylpehol ethoxylates by Fenton and $\mathrm{H}_{2} \mathrm{O}_{2} / \mathrm{UV}$ processes, while Lechuga et al. (2014) indicated that the removal of LAS is increased by the consecutive use of ozonation and biodegradation. However, the degradation of new families of surfactants by AOPs, such as ether carboxylic derivates remains unstudied.

In order to contribute to increasing the information concerning the effectiveness of different AOPs, the present investigation was specifically aimed at the degradation of two different anionic surfactants by direct photolysis and advanced oxidation in $\mathrm{H}_{2} \mathrm{O}_{2} / \mathrm{UVC}$ system. The influence of various parameters in the degradation $(\mathrm{pH}$, initial surfactant concentration and dose of hydrogen peroxide) was also studied.

\section{Methods}

Two anionic surfactants were used in this study: linear alkyl benzene sulfonate (LAS- $\mathrm{R}_{11-14}$ ), supplied by Petresa (Madrid, Spain), and ether carboxylic derivate $\left(E C-R_{12-14} E_{10}\right)$ supplied by Kao Corporation S.A. (Tokyo, Japan). Table 1 shows the structure, the percentage of active matter and the critical micelle concentration (CMC) of the surfactants tested. The initial surfactants concentrations used ranged from 9.3 to $60.0 \mathrm{mg} \mathrm{dm}^{-3}$ and from 6.4 to $89.3 \mathrm{mg} \mathrm{dm}^{-3}$ for LAS-R ${ }_{11-14}$ and EC- $\mathrm{R}_{12-14} \mathrm{E}_{10}$, respectively. These concentrations were chosen in order to study the degradation of surfactants above and below the $\mathrm{CMC}$. The used concentration of hydrogen peroxide $(30 \%)\left(\mathrm{POCH}\right.$, Poland) ranged from $1 \times 10^{-2} \mathrm{~mol} \mathrm{dm}^{-3}$ to $1 \times 10^{-1} \mathrm{~mol} \mathrm{dm}^{-3}$.

All the solutions used in the experiments were prepared in distilled water treated in Millipore Milli-Q Plus System and the $\mathrm{pH}$ of the solutions was adjusted by a phosphate buffer $\left(\mathrm{H}_{3} \mathrm{PO}_{4}\right.$, $\mathrm{KH}_{2} \mathrm{PO}_{4}, \mathrm{Na}_{2} \mathrm{HPO}_{4}, \mathrm{NaOH}$, all p.a., POCh, Poland) in the range from 2 to 12 .

For both process: UVC photolysis and the $\mathrm{H}_{2} \mathrm{O}_{2} / \mathrm{UVC}$ system, low-pressure lamps (Luzchem) emitting mainly at the wavelength $\lambda=254 \mathrm{~nm}$ were applied. The tested solutions were irradiated in a merry-go-round device with quartz test tubes (volume: $10 \mathrm{~cm}^{3}$, average optical path length: $0.85 \mathrm{~cm}$ ), placed between two exposure panels, each of them consisting of three $7.2 \mathrm{~W}$ lamps. The samples were irradiated for $120 \mathrm{~min}$ in the case of UVC photolysis and for $4 \mathrm{~min}$ when the $\mathrm{H}_{2} \mathrm{O}_{2} / \mathrm{UV}$ system was used. In the case of $\mathrm{H}_{2} \mathrm{O}_{2} / \mathrm{UV}$ system, degradation experiments were additionally performed in the presence of hydroxyl radicals scavenger. In these studies $1 \times 10^{-1} \mathrm{~mol} \mathrm{dm}^{-3}$ tert-butanol (Fluka) was used. The experiments were performed at room temperature equal to $22^{\circ} \mathrm{C}$.

The surfactant degradation was monitored by means of the residual-surfactant concentration over time using a colorimetric method in which the absorbance is directly proportional to the surfactant concentration. The method is based on the formation of the ionic-pair anionic surfactant-methylene blue (Jurado et al. 2006). For spectrophotometric measurements, $5 \times 10^{-3} \mathrm{dm}^{3}$ of sample placed in $1 \times 10^{-2} \mathrm{dm}^{3}$ glass vials were made alkaline to $\mathrm{pH} 10.0$ by adding $2 \times 10^{-4} \mathrm{dm}^{3}$ of $5 \times 10^{-2} \mathrm{~mol} \mathrm{dm}^{-3}$ sodium tetraborate, $\mathrm{pH} 10.5$, and then $10^{-4} \mathrm{dm}^{3}$ of methylene blue $1 \mathrm{~g} \mathrm{dm}^{-3}$ stabilized was added. Finally, $4 \times 10^{-3} \mathrm{dm}^{3}$ of chloroform was added and, after stirring and 5-min wait, the absorbance at $650 \mathrm{~nm}$ was measured. This method allows to measure the concentration of LAS- $\mathrm{R}_{11-14}$ and EC- $\mathrm{R}_{12-14} \mathrm{E}_{10}$ with a limit of detection of $0.05 \mathrm{mg} \mathrm{dm}^{-3}$.

The initial reaction rates were calculated by differentiating exponential curve that fitted experimental points $(\mathrm{C}, \mathrm{t})$ at the correlation factor higher than 0.97 .

\section{Results and discussion}

In the beginning, the possibility of surfactants degradation during exposure to UVC radiation was tested.

Fig. 1 presents absorption spectra of the tested substances at different $\mathrm{pH}$ and the emission spectrum of the UV lamps. LAS- $\mathrm{R}_{11-14}$ molecules absorb radiation with maximum at $224 \mathrm{~nm}$, while EC- $\mathrm{R}_{12-14} \mathrm{E}_{10}$ very poorly absorbs UVC radiation.

The investigated compounds were irradiated for 120 minutes and the influence of their initial concentration and

Table 1. Description of the surfactants used ( $\mathrm{R}$ : alkyl-chain length, $\mathrm{n}$ : degree of ethoxylation, $\mathrm{X}=\mathrm{H}^{+}$or $\mathrm{Na}$ )

\begin{tabular}{|l|l|l|}
\hline Surfactant & Linear alkyl benzene & Ether carboxylic derivative \\
\hline Abbreviation & LAS- $\mathrm{R}_{11-14}$ & $\mathrm{EC}-\mathrm{R}_{12-14} \mathrm{E}_{10}$ \\
\hline Structure & $\mathrm{R}-\mathrm{CH}-\left(\mathrm{CH}_{3}\right)\left(\mathrm{C}_{6} \mathrm{H}_{4}\right)-\mathrm{SO}_{3}-\mathrm{Na}^{+}$ & $\mathrm{R}-\left(\mathrm{CH}_{2}-\mathrm{CH}_{2} \mathrm{O}\right)_{\mathrm{n}}-\mathrm{O}-\mathrm{CH}_{2}-\mathrm{COO}-\mathrm{X}$ \\
\hline$\%$ Active Matter & $46.8^{\mathrm{a}}$ & $94.0^{\mathrm{a}}$ \\
\hline $\mathrm{CMC}, \mathrm{mg} \mathrm{dm}^{-3}$ & $25.5^{\mathrm{b}}$ & $69.0^{\mathrm{b}}$ \\
\hline
\end{tabular}

a Supplied by the manufacturer

${ }^{b}$ (Lechuga et al. 2013) 
$\mathrm{pH}$ were studied. Fig. 2 shows changes of relative surfactant concentration versus radiation dose (E). The degradation of investigated compounds during photolysis by $254 \mathrm{~nm}$ irradiation occurs slowly and is a highly energy-consuming process. The use of radiation dose of $57.2 \mathrm{~kJ} \mathrm{~m}^{-2}$ results in about $10 \%$ reduction of initial surfactants concentration (Fig. 2). While, the UV disinfection dose usually applied for tap water treatment is equal to $0.4 \mathrm{~kJ} \mathrm{~m}^{-2}$ (Canonica et al. 2008), therefore it is no possible to remove these compounds during disinfection process.

In the case of EC- $\mathrm{R}_{12-14} \mathrm{E}_{10}$, the photolysis occurs the fastest in neutral $\mathrm{pH}$ (Fig. 3A), while the increase in alkalinity practically does not influence the reaction rate of LAS-R ${ }_{11-14}$ photolysis (Fig. 3A). An increase in the initial concentration caused increase of $E C-R_{12-14} E_{10}$ reaction rate (Fig. 3B), and did not accelerate the LAS-R ${ }_{11-14}$ photodegradation (Fig. 3B).

The addition of hydrogen peroxide to the reaction solution resulted in a significant acceleration of degradation process (Fig. 2). A 10-fold lower radiation dose $\left(5.72 \mathrm{~kJ} \mathrm{~m}^{-2}\right)$ than mentioned above for photolysis allows for $60 \%$ reduction of initial LAS-R ${ }_{11-14}$ concentration (Fig. 2A) and about 50\% reduction of initial EC- $\mathrm{R}_{12-14} \mathrm{E}_{10}$ concentration (Fig. 2B). Pagano et al. (2008) also found high removal rates of surfactants: alcohol ethoxylates and alkylphenol ethoxylates using the $\mathrm{H}_{2} \mathrm{O}_{2} / \mathrm{UV}$ process.

The degradation in the $\mathrm{H}_{2} \mathrm{O}_{2} / \mathrm{UV}$ system requires establishing of an optimal hydrogen peroxide concentration,

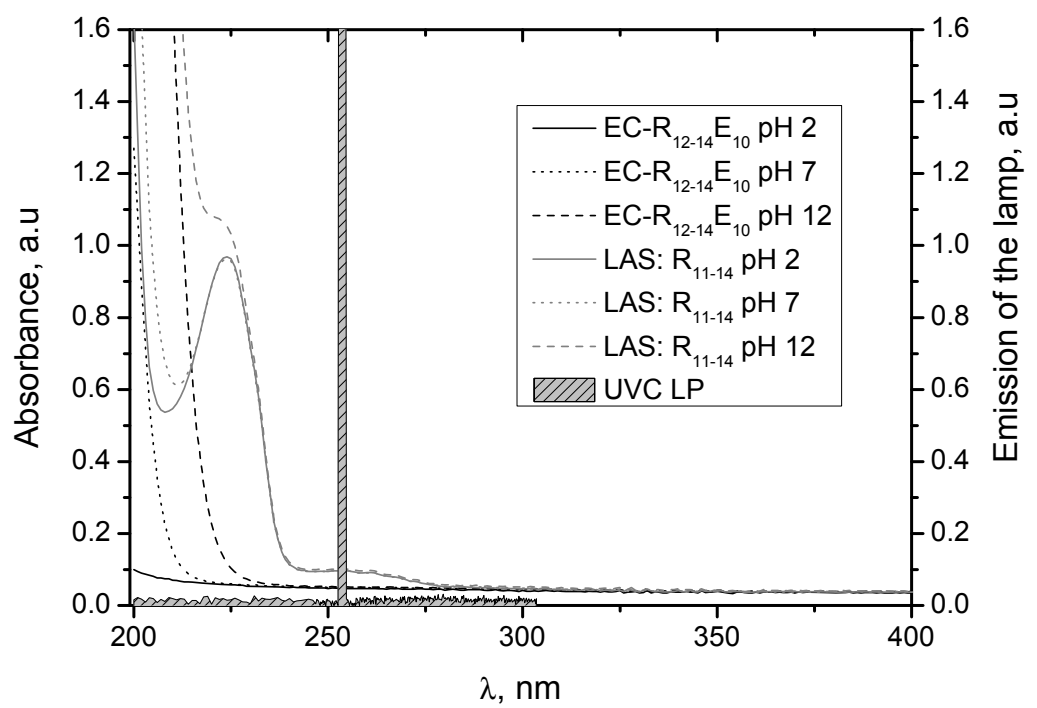

Fig. 1. Absortion spectra of LAS- $R_{11-14}(A)\left(C_{0}=45 \mathrm{mg} \mathrm{dm}^{-3}\right)$ and $E C-R_{12-14} E_{10}(B)\left(C_{0}=26 \mathrm{mg} \mathrm{dm}^{-3}\right)$ at $p H=2,7$ and 12, overlayed against emission spectra of UVC lamps used in experiments

A)

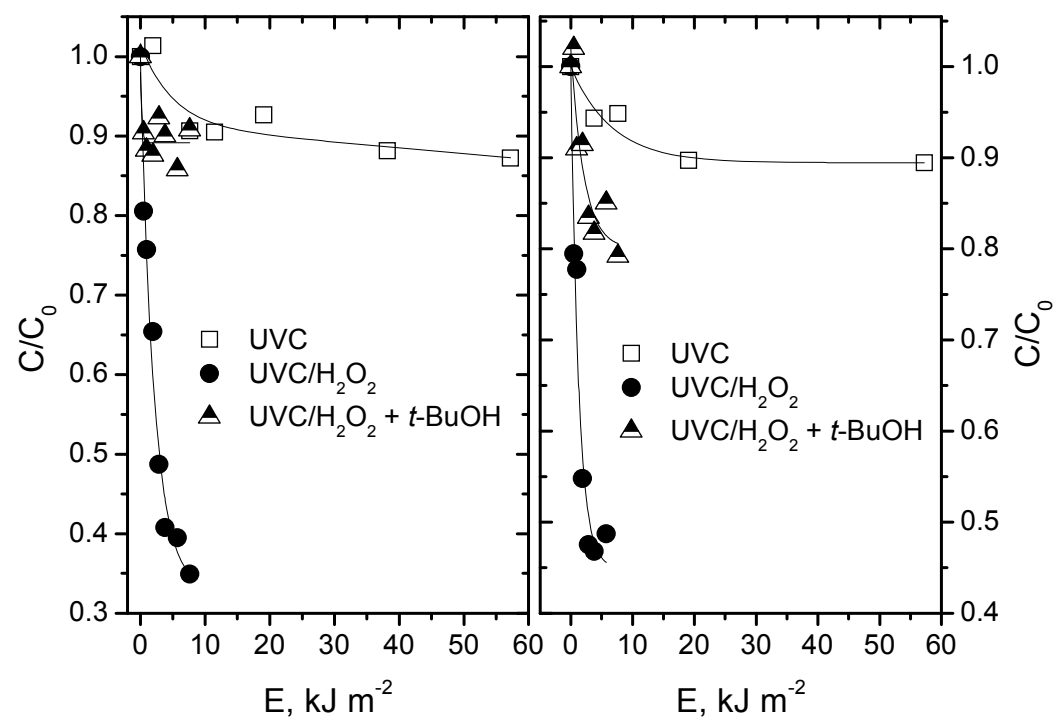

Fig. 2. Changes of relative LAS- $R_{11-14}(A)\left(C_{0}=45 \mathrm{mg} \mathrm{dm}^{-3}, C_{\mathrm{H} 2 \mathrm{O} 2}=3 \times 10^{-2} \mathrm{~mol} \mathrm{dm}^{-3}, C_{\mathrm{tBuOH}}=1 \times 10^{-1} \mathrm{~mol} \mathrm{dm}^{-3}, \mathrm{pH}=7\right.$, $E_{0}=10.6 \times 10^{-6}$ einstein $\left.\mathrm{dm}^{-3} \mathrm{~s}^{-1}\right)$ and EC- $\mathrm{R}_{12-14} \mathrm{E}_{10}(\mathrm{~B})\left(\mathrm{C}_{0}=26 \mathrm{mg} \mathrm{dm}^{-3}, \mathrm{C}_{\mathrm{H} 2 \mathrm{O} 2}=3 \times 10^{-2} \mathrm{~mol} \mathrm{dm}^{-3}, \mathrm{C}_{\mathrm{tBuOH}}=1 \times 10^{-1} \mathrm{~mol} \mathrm{dm}^{-3}\right.$, $\mathrm{pH}=7, \mathrm{E}_{0}=10.6 \times 10^{-6}$ einstein $\mathrm{dm}^{-3} \mathrm{~s}^{-1}$ ) concentration during the photolysis and advanced oxidation 
i.e. when the $\mathrm{H}_{2} \mathrm{O}_{2}$ photolysis produces plenty of $\bullet \mathrm{OH}$ radicals and their consumption by hydrogen peroxide is negligible. The highest reaction rate of the surfactants degradation was attained at $\mathrm{H}_{2} \mathrm{O}_{2}$ concentration of $3 \times 10^{-2} \mathrm{~mol} \mathrm{dm} \mathrm{dm}^{-3}$, as shown in Fig. 4. This optimal $\mathrm{H}_{2} \mathrm{O}_{2}$ concentration was chosen to evaluate the influence of other parameters on the advanced oxidation of the investigated surfactants in $\mathrm{H}_{2} \mathrm{O}_{2} / \mathrm{UV}$ system.

The results of advanced oxidation in $\mathrm{H}_{2} \mathrm{O}_{2} / \mathrm{UV}$ system at various $\mathrm{pH}$ of reaction solutions are presented in Fig. 5. In the case of LAS- $\mathrm{R}_{11-14}$ the process occurs with a similar efficiency at neutral and acidic conditions (Fig. 5A), whereas for $\mathrm{EC}-\mathrm{R}_{12-14} \mathrm{E}_{10}$ it is the most effective at pH 7 (Fig. 5B). In alkaline solutions degradation of investigated compounds was strongly inhibited, which is mainly connected with the hydrogen peroxide dissociation (1) $\left(\mathrm{pK}_{\mathrm{a}}=11.6\right.$ (Hoigne 1998)). The anions formed in this reaction have a much higher molar absorption coefficient in comparison to hydrogen peroxide $\left(\varepsilon_{254 \mathrm{~nm}}=240 \mathrm{M}^{-1} \mathrm{~cm}^{-1}\right.$ (Legrini et al. 1993), $\varepsilon_{254 \mathrm{~nm}}=18.6 \mathrm{M}^{-1} \mathrm{~cm}^{-1}$ (Nicole et al. 1990)), and can react both with $\mathrm{H}_{2} \mathrm{O}_{2}(2)$ and $\bullet{ }^{\bullet} \mathrm{OH}$ (3) radicals leading to reduction of $\bullet \mathrm{OH}$ radicals concentration in the reaction mixture.

$$
\begin{gathered}
\mathrm{H}_{2} \mathrm{O}_{2}+\mathrm{H}_{2} \mathrm{O} \rightarrow \mathrm{H}_{3} \mathrm{O}^{+}+\mathrm{HO}_{2}^{-} \\
\mathrm{H}_{2} \mathrm{O}_{2}+\mathrm{HO}_{2}^{-} \rightarrow \mathrm{H}_{2} \mathrm{O}+\mathrm{O}_{2}+\bullet \mathrm{OH}^{-} \\
\bullet \mathrm{OH}+\mathrm{HO}_{2}^{-} \rightarrow \mathrm{H}_{2} \mathrm{O}+\mathrm{O}_{2}^{\bullet-}
\end{gathered}
$$

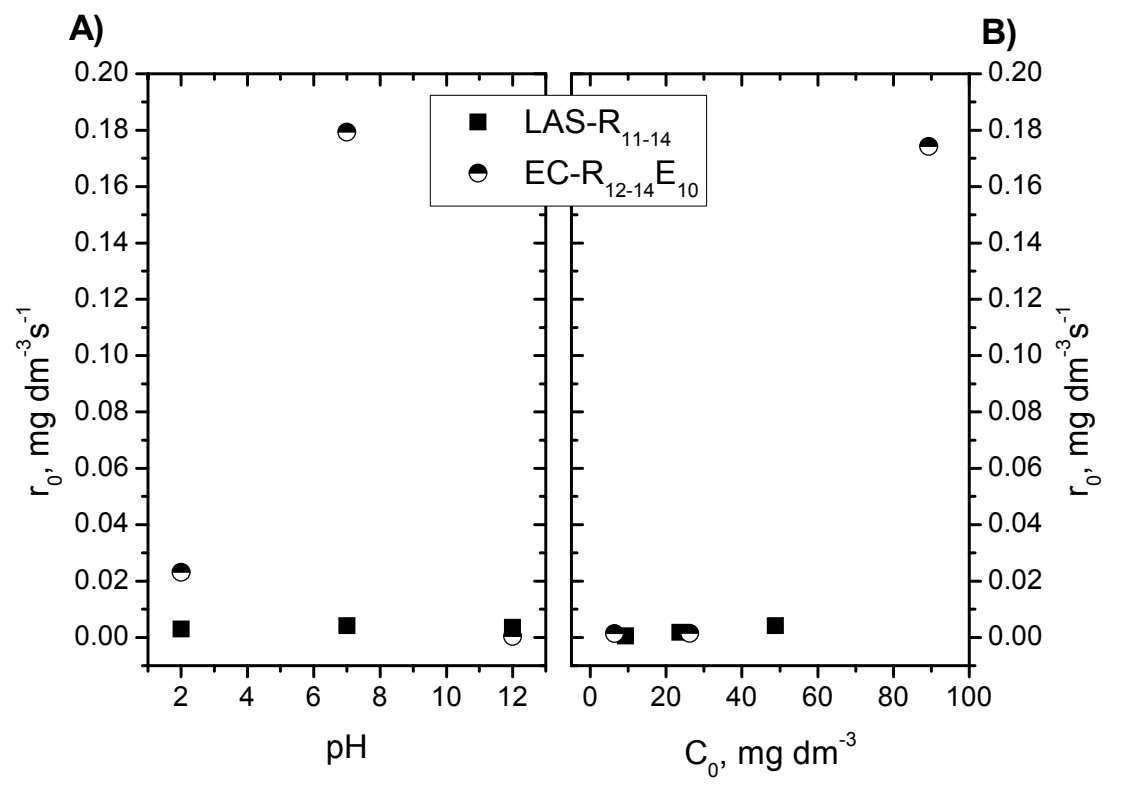

Fig. 3. Influence of $\mathrm{pH}(\mathrm{A})\left(\mathrm{LAS}: \mathrm{R}_{11-14}: \mathrm{C}_{0}=46 \mathrm{mg} \mathrm{dm}^{-3}, \mathrm{E}_{0}=10.6 \times 10^{-6}\right.$ einstein $\mathrm{dm}^{-3} \mathrm{~s}^{-1} ; \mathrm{EC} \mathrm{R}_{12-14} \mathrm{E}_{10}: \mathrm{C}_{0}=30 \mathrm{mg} \mathrm{dm}^{-3}$, $E_{0}=10.6 \times 10^{-6}$ einstein $\left.\mathrm{dm}^{-3} \mathrm{~s}^{-1}\right)$ and initial surfactant concentration $(B)\left(E_{0}=10.6 \times 10^{-6}\right.$ einstein $\left.\mathrm{dm}^{-3} \mathrm{~s}^{-1}, \mathrm{pH}=7\right)$ on initial reaction rate

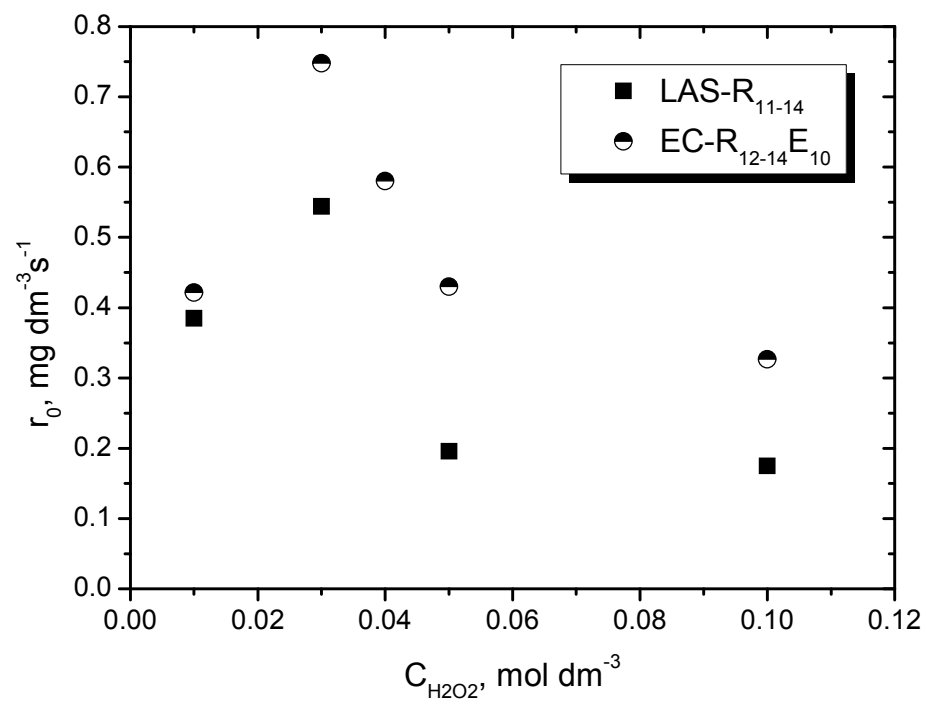

Fig. 4. Dependence of initial reaction rate on hydrogen peroxide concentration $\left(L A S-R_{11-14}: C_{0}=50 \mathrm{mg} \mathrm{dm}^{-3}\right.$, $\mathrm{pH}=7, \mathrm{E}_{0}=10.6 \times 10^{-6}$ einstein $\mathrm{dm}^{-3} \mathrm{~s}^{-1} ; \mathrm{EC}-\mathrm{R}_{12-14} \mathrm{E}_{10}: \mathrm{C}_{0}=40 \mathrm{mg} \mathrm{dm}^{-3}, \mathrm{pH}=7, \mathrm{E}_{0}=10.6 \times 10^{-6}$ einstein dm $\mathrm{dm}^{-3}$ ) 
The surfactant degradation at four different initial concentrations was studied (Fig. 6). In the case of LAS-R ${ }_{11-14}$, there is an optimal concentration $\left(26 \mathrm{mg} \mathrm{dm}^{-3}\right)$ above which degradation process slowed down (Fig. 6A), what can be explained by the advantage of this compounds over $\mathrm{H}_{2} \mathrm{O}_{2}$ in the competition of photons and domination of direct photolysis of LAS-R ${ }_{11-14}$. CMC of LAS-R ${ }_{11-14}$ is equal to $25.5 \mathrm{mg} \mathrm{dm}^{-3}$ (Table 1) and the optimal concentration coincides with this value, i.e. when the solubilization of the surfactant molecules takes place in micelles. However, at concentrations above the $\mathrm{CMC}$ the degradation does not occur faster, and the percentage of degradation is lower (Fig. 6A). In addition, this process slowed down when the LAS- $\mathrm{R}_{11-14}$ concentration was below CMC due to the fact that the molecules of surfactants were mainly in the water-air interface and access to them was more difficult.

In the degradation process of $\mathrm{EC}-\mathrm{R}_{12-14} \mathrm{E}_{10}$, increase of initial concentration leads to the acceleration of reaction efficiency and reducing the energy input (Fig. 6B). During advanced oxidation of EC- $\mathrm{R}_{12-14} \mathrm{E}_{10}, 40 \%$ reduction of the initial concentration equal to $7.5 \mathrm{mg} \mathrm{dm}^{-3}$ was achieved by using radiation dose of $3.81 \mathrm{~kJ} \mathrm{~m}^{-2}$. About 6 -fold higher initial concentration of these compounds results in 4-fold decreases of radiation dose which is needed to achieve the above degradation degree (Fig. 6B). The influence of CMC on advanced oxiadation of EC- $\mathrm{R}_{12-14} \mathrm{E}_{10}$, cannot be studied because its initial concentration was below CMC in all cases.

\section{A)}

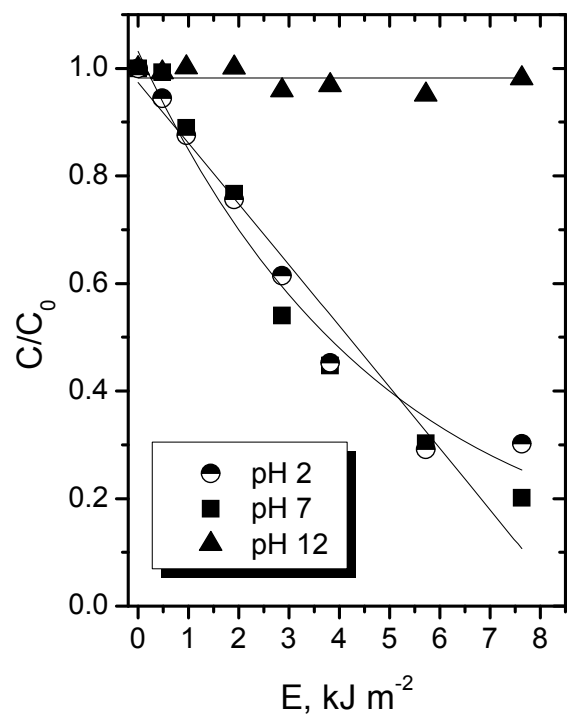

B)

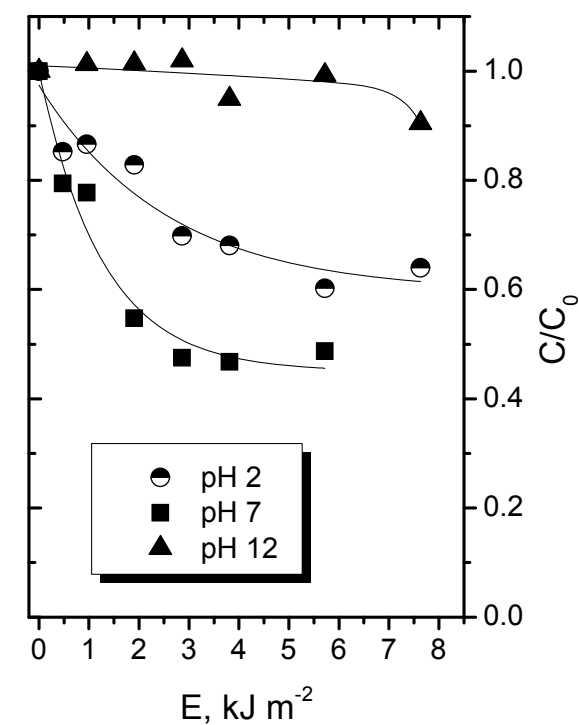

Fig. 5. Changes of relative LAS- $R_{11-14}(A)\left(C_{0}=54 \mathrm{mg} \mathrm{dm}^{-3}, C_{\mathrm{H}_{2} \mathrm{O} 2}=3 \times 10^{-2} \mathrm{~mol} \mathrm{dm}^{-3}, E_{0}=10.6 \times 10^{-6}\right.$ einstein dm $\left.{ }^{-3} \mathrm{~s}^{-1}\right)$ and $E C-R_{12-14} E_{10}$ (B) $\left(C_{0}=26 \mathrm{mg} \mathrm{dm}^{-3}, \mathrm{C}_{\mathrm{H} 2 \mathrm{O} 2}=3 \times 10^{-2} \mathrm{~mol} \mathrm{dm}^{-3}, \mathrm{E}_{0}=10.6 \times 10^{-6}\right.$ einstein $\left.\mathrm{dm}^{-3} \mathrm{~s}^{-1}\right)$ concentration during advanced oxidation in various $\mathrm{pH}$ values

A)

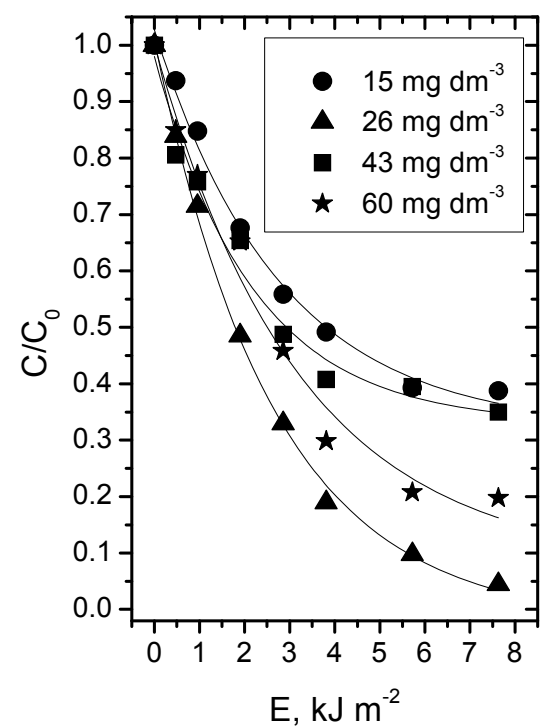

B)

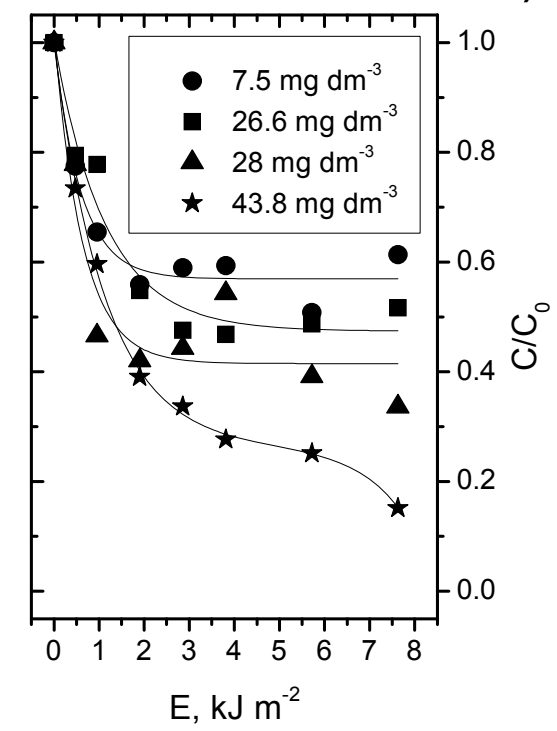

Fig. 6. Changes of relative LAS- $R_{11-14}(A)\left(C_{\mathrm{H}_{2} \mathrm{O} 2}=3 \times 10^{-2} \mathrm{~mol} \mathrm{dm}^{-3}, \mathrm{pH}=7, \mathrm{E}_{0}=10.6 \times 10^{-6}\right.$ einstein $\left.\mathrm{dm}^{-3} \mathrm{~s}^{-1}\right)$ and $\mathrm{EC}-\mathrm{R}_{12-14} \mathrm{E}_{10}(\mathrm{~B})\left(\mathrm{C}_{\mathrm{H} 2 \mathrm{O} 2}=3 \times 10^{-2} \mathrm{~mol} \mathrm{dm}^{-3}, \mathrm{pH}=7, \mathrm{E}_{0}=10.6 \times 10^{-6}\right.$ einstein $\left.\mathrm{dm}^{-3} \mathrm{~s}^{-1}\right)$ concentration during advanced oxidation for various intial concetrantion of surfactant 
In addition, surfactant degradation was studied in the presence of hydroxyl radical scavengers (Fig. 2). The influence of tert-butanol on the reaction run was investigated. For both surfactants, the reaction is not inhibited to the direct photolysis level, what may suggest that an additional reaction ("third pathway") occurs. Similar situation was observed during butylparaben (Błędzka et al. 2010) and fluorene (Ledakowicz et al. 1999) degradation in $\mathrm{H}_{2} \mathrm{O}_{2} / \mathrm{UV}$ system.

\section{Conclusions}

The studies performed on degradation of two surfactants: linear alkyl benzene sulphonate and ether carboxylic derivate exposed to UVC irradiation in aqueous solutions with and without addition of hydrogen peroxide enable us to draw the following conclusions.

The photolysis of EC- $\mathrm{R}_{12-14} \mathrm{E}_{10}$ occurs the fastest in neutral $\mathrm{pH}$, while the increase in alkalinity practically does not influence reaction rate of LAS- $\mathrm{R}_{11-14}$ photolysis.

An increase in the initial concentration of surfactants caused increase of photolysis rate.

Advanced oxidation of EC- $\mathrm{R}_{12-14} \mathrm{E}_{10}$ is the most effective at $\mathrm{pH}$ 7, whereas for LAS- $\mathrm{R}_{11-14}$ it occurs with a similar efficiency at neutral and acidic conditions. However, for both investigated compounds this process was strongly inhibited in alkaline solutions.

The highest degradation rate of surfactants in $\mathrm{H}_{2} \mathrm{O}_{2} / \mathrm{UV}$ system was attained at $\mathrm{H}_{2} \mathrm{O}_{2}$ concentration of $3 \times 10^{-2} \mathrm{~mol} \mathrm{dm}^{-3}$.

Increase of $\mathrm{EC}-\mathrm{R}_{12-14} \mathrm{E}_{10}$ initial concentration leads to the acceleration of advanced oxidation, while in the case of LAS- $\mathrm{R}_{11-14}$, there is an optimal concentration above which degradation process slowed down.

Advanced oxidation process in a $\mathrm{H}_{2} \mathrm{O}_{2} / \mathrm{UV}$ system represents an effective method to degrade surfactants. This technique has advantages over using photolysis alone: degradation is a faster and less energy-consuming process.

\section{References}

Aloui, F., Kchaou, S. \& Sayadi, S. (2009). Physicochemical treatments of anionic surfactants wastewater: effect on aerobic biodegradability, Journal of Hazardous Materials, 164, 1, pp. 353-359.

Błędzka, D., Gryglik, D., Olak, M., Gębicki, J.L. \& Miller, J.S. (2010). Degradation of n-butylparaben and 4-tertoctylphenol in H2O2/UV system, Radiation Physics and Chemistry, 79, 4, pp. 409-416.

Bozkurt, H. \& Sanin, F.D. (2014). Toxicity of nonylphenol diethoxylate in lab-scale anaerobic digesters, Chemosphere, 104, pp. 69-75.

Braga, J.K. \& Varesche, M.B.A. (2011). Commercial laundry water characterization for anaerobic treatment in fluidized bed reactor. X Oficina e Seminario Latino Americano de Digestão Anaeróbia (DAAL), Ouro Preto.

Canonica, S., Meunier, L. \& von Gunten, U. (2008). Phototransformation of selected pharmaceuticals during UV treatment of drinking water, Water Research, 42, 1-2, pp. 121-128.

CESIO. (2014). CESIO news. European Committee of Organic Surfactants and their Intermediates, Issue 15, September 2014.

Chidambara, C.B. \& Quen, H.L. (2005). Advanced oxidation processes for wastewater treatment: Optimization of $\mathrm{UV} / \mathrm{H}_{2} \mathrm{O}_{2}$ process through a statistical technique, Chemical Engineering Science, 60, 19, pp. 5305-5311.

Cserháti, T., Forgács, E. \& Orgos, G. (2002). Biological activity and environmental impact of anionic surfactants, Environmental International, 28, pp. 337-348.
Fernández-Serrano, M., Jurado, E., Fernández-Arteaga, A., Ríos, F. \& Lechuga, M. (2014). Ecotoxicological assessment of mixtures of ether carboxylic derivative and amine-oxide-based non-ionic surfactants on the aquatic environment, Journal of Surfactants and Detergents, 17, 6, pp. 1161-1168.

Ferrara, F., Fabietti, F., Delise, M. \& Funari, E. (2005). Alkylphenols and alkylphenol ethoxylates contamination of crustaceans and fishes from the Adriatic Sea (Italy), Chemosphere, 59, 8, pp. $1145-1150$.

Hoigne, J. (1998). Chemistry of aqueous ozone and transformation of pollutants by ozonation and advanced oxidation processes, In: Quality and treatment of drinking water II, Hrubec, J. (Eds.). Springer-Verlag, Berlin, Heidelberg, Germany 1998.

Human and Environmental Risk Assessments (HERA). (2013). Linear alkylbenzene sulphonate. Revised HERA report. April 2013. Retrieved from: (http://www.heraproject.com (03.11.2016)).

Ikehata, K. \& El-Din, M.G. (2004). Degradation of recalcitrant surfactants in wastewater by ozonation and advanced oxidation processes: A review, Ozone Science and Engineering, 26, 4, pp. 327-343.

Jurado, E., Fernández-Serrano, M., Nuñez-Olea, J., Luzón, G. \& Lechuga, M. (2006). Simplified spectrophotometric method using methylene blue for determining anionic surfactants: Applications to the study of primary biodegradation in aerobic screening tests, Chemosphere, 65, 2, pp. 278-285.

Jurado, E., Fernández-Serrano, M., Ríos, F. \& Lechuga, M. (2013). Aerobic biodegradation of surfactants, In: Biodegradation - life of science, Chamy, R. \& Rosenkranz, F. (Eds.), pp. 66-81. InTech, Rijeka, Croatia 2013.

Kuczajowska-Zadrożna, M., Filipkowska, U. \& Jóźwiak, T. (2015) Application of biosurfactants for heavy netals leaching from immobilized activated sludge, Archives of Environmental Protection, 41, pp. 43-52.

Lechuga, M., Fernández-Arteaga, A., Fernández-Serrano, M., Jurado, E., Burgos, A. \& Ríos, F. (2013). Ozonation of anionic and non-ionic surfactants in aqueous solutions: impact on aquatic toxicity, Journal of Surfactants and Detergents, 16, pp. 779-784.

Lechuga, M., Fernández-Arteaga, A., Fernández-Serrano, M., Jurado, E., Burgos, A. \& Ríos, F. (2014). Combined use of ozonation and biodegradation of anionic and non-ionic surfactants, Journal of Surfactants and Detergents, 17, pp. 363-370.

Ledakowicz, S., Miller, J.S. \& Olejnik, D. (1999). Oxidation of PAHs in water solutions by ultraviolet radiation combined with hydrogen peroxide, International Journal of Photoenergy, 1, pp. 55-60.

Ledakowicz, S., Perkowski, J., Bulska, A., Jamroz, T. \& Sencio, B. (2005). Ozonation impact on degradation and toxicity of non-ionic surfactants, Ozone Science and Enginnering, 27, 6, pp. $437-445$.

Legrini, O., Oliveros, E. \& Braun, A.M. (1993). Photochemical processes for water treatment, Chemical Reviews, 93, 2, pp. 671-698.

Liwarska-Bizukojc, E. \& Bizukojc, M. (2008). Estimation of the impact of anionic surfactants on activated sludge flocs morphology in a batch system, Archives of Environmental Protection, 34, 4, pp. 25-34.

Luo, Y., Guo, W., Ngo, H.H., Nghiem, L.D., Hai, F.I., Zhang, J., Liang, S. \& Wang, X.C. (2014). A review on the occurrence of micropollutants in the aquatic environment and their fate and removal during wastewater treatment, Science of the Total Environment, 473-474, pp. 619-641.

Markets and Markets (2013). Surfactants market by product types [anionic, non-ionic, cationic, amphoteric], substrates [synthetic/ petrochemical, bio-based/natural/green], geography and applications-Global industry trends and forecast to 2017.

Nicole, I., De Laat, J., Dore, M., Duguet, J. \& Bonnel, C. (1990). Use of UV radiation in water treatment: measurement of photonic 
flux by hydrogen peroxide actinometry, Water Research, 24, 2, pp. 157-168. (in French)

Pagano, M., Lopez, A., Volpe, A., Mascolo, G. \& Ciannarella, R. (2008). Oxidation of nonionic surfactants by Fenton and $\mathrm{H}_{2} \mathrm{O}_{2}$ / UV processes, Environmental Technology, 29, pp. 423-433.

Petrovic, M., Rodriguez. A., Borrull, F., Marce, R.M., González, E. \& Barceló, D. (2002). Occurrence and distribution of nonionic surfactants, their degradation products, and linear alkylbenzene sulfonates in coastal waters and sediments in Spain, Environmental Toxicology and Chemistry, 21, 1, pp. 37-46.

Rebello, S., Asok, A.K., Mundayoor, S. \& Jisha, M.S. (2014). Surfactants: toxicity, remediation and green surfactants, Environmental Chemistry Letters, 12, 2, pp. 275-287.

Robert-Peillar, F., Syakti, A.D., Coulomb, B., Doumenq, P., Malleret, L., Asia, L. \& Boudenne, J.L. (2015). Occurrence and fate of selected surfactants in seawater at the outfall of the Marseille urban sewerage system, International Journal of Environmental Science and Technology, 12, pp. 1527-1538.

Roberts, D.W. \& Marshall, S.J. (1995). Application of hydrophobicity parameters to prediction of the acute aquatic toxicity of commercial surfactant mixtures, SAR and QSAR in Environmental Research, 4, pp.167-176.

Sanz, J., Lombraña, J.I. \& De Luis, A. (2013). Temperature-assisted $\mathrm{UV} / \mathrm{H} 2 \mathrm{O} 2$ oxidation of concentrated linear alkylbenzene sulphonate (LAS) solutions, Chemical Engineering Journal, 215-216, pp. 533-541.

Ying, G.-G. (2006). Fate, behaviour and effects of surfactants and their degradation products in the environment, Environmental International, 32, 3, pp. 417-431.

Zgoła-Grześkowiak, A., Grześkowiak, T. \& Szymański, A. (2015). Biodegradation of nonylphenol monoproxyethoxylates, Journal of Surfactants and Detergents, 18, pp. 355-364.

\section{Efektywność usuwania surfaktantów anionowych z wody przy zastosowaniu promieniowania UVC i zaawansowanego utleniania w układzie $\mathrm{H}_{2} \mathrm{O}_{2} / \mathrm{UVC}$}

Streszczenie: Surfaktanty, podobnie jak większość tego typu substancji chemicznych, po wykorzystaniu trafiają do środowiska wodnego. Związki te mogą stwarzać zagrożenie dla flory i fauny zasiedlającej wody powierzchniowe, jak również mogą działać toksycznie na mikroorganizmy znajdujące się w osadzie czynnym w oczyszczalniach ścieków.

W niniejszej pracy przedstawiono wyniki badań degradacji wybranych surfaktantów anionowych w środowisku wodnym przy zastosowaniu promieniowania UVC i zaawansowanego utleniania w układzie $\mathrm{H}_{2} \mathrm{O}_{2} / \mathrm{UVC}$. Zbadano wpływ następujących parametrów reakcyjnych: odczyn środowiska reakcyjnego, początkowego stężenia obiektów badań i nadtlenku wodoru na szybkość degradacji surfaktantów. Uzyskane w toku prac badawczych wyniki potwierdzają wysoką skuteczność zaawansowanego utleniania w układzie $\mathrm{H}_{2} \mathrm{O}_{2} / \mathrm{UVC}$ w usuwaniu badanych surfaktantów ze środowiska wodnego, które jest procesem znacznie efektywniejszym w porównaniu do procesu fotolizy. 